\title{
Determination of fluconazole in serum and amniotic fluid of rats by gas- chromatography/mass spectometry (GC/MS)
}

\author{
Dione Marçal Lima', Guilhermino Pereira Nunes Júnior², Pedro Henrique Ferri ${ }^{3}$, Suzana Costa Santos ${ }^{3^{*}}$ \\ Faculdade de Farmácia', Departamento de Fisiologia e Farmacologia, Instituto de Ciências Biológicas², Laboratório \\ de Bioatividade Molecular, Instituto de Química33, Universidade Federal de Goiás.
}

*Correspondence:

S.C. Santos

Laboratório de Bioatividade Molecular,

Instituto de Química, Universidade

Federal de Goiás - C.P. 131

74001-970, Goiânia, Brasil

E-mail address: suzana@quimica.ufg.br
Rats treated with oral dose of $100 \mathrm{mg} / \mathrm{kg}$ of fluconazole during pregnancy had their serum and amniotic fluid quantified for this drug using a GC/MS method. Fluconazole was extracted with ethyl acetate from samples and analysed by a GC-MS Shimadzu QP5050A system using a CBP-5 fused silica capillary column. Tioconazole was used as internal standard. Calibration curve was linear within the range $10.0-300.0 \mu \mathrm{g} / \mathrm{mL}$. The limit of quantification was $0.1 \mu \mathrm{g} / \mathrm{mL}$ and no interference was observed in the blank serum and amniotic liquid. The mean concentrations of the drug in the serum and amniotic fluid were $206.01 \pm 105.25 \mu \mathrm{g} / \mathrm{mL}$ and 125.34 $\pm 65.24 \mu \mathrm{g} / \mathrm{mL}$, respectively. This procedure showed to be sensitive and efficient enough for the use in teratogenic studies of fluconazole and other azole drugs.

\section{INTRODUCTION}

Fluconazole, (2,4-difluoro- $\alpha, \alpha$ '-bis(1H-1,2,4-triazol-1ylmethyl)benzyl alcohol, is a broad-spectrum triazole antifungal agent, which has shown to be active against systemic and superficial infections (Richardson et al., 1985). Studies on the pharmacokinetics of fluconazole showed: rapid absorption after oral administration, no metabolization, approximately $80 \%$ is excreted unchanged in the urine, and a wide distribution in several organs in the body (Ripa et al., 1993; Debruyne and Ryckelynck, 1993). Recently, some reports pointed out the adverse effects of fluconazole on pregnancy (King et al., 1998). Cases of newborns with skeleton and cranium malformations, and heart problems suggested that high doses of this drug $(400-800 \mathrm{mg} /$ day $)$ might be teratogenic (Mastroiacovo et al., 1996; Pursley et al., 1996; Polifka, Friedman, 1999). Despite the observed effects on the development of the foetus, there is no evidence until now about the transference of fluconazole through placenta. Although several analytical chromatographic methods have been developed to analyse fluconazole in biological fluids (Wood, Tarbit, 1986; Beijnen et al., 1991; Koks et al., 1995; $\mathrm{Ng}$ et al., 1996; Majcherczyk et al., 2002; Eerkes et al., 2003), there are no reports of fluconazole quantification in amniotic liquid. The objective of this study was to develop a simple assay for determination of fluconazole in serum and amniotic fluid of rats treated with oral dose of $100 \mathrm{mg} / \mathrm{kg}$ of the drug during pregnancy, which will be useful in further teratogenic studies.

\section{EXPERIMENTAL}

\section{Chemicals}

Fluconazole was obtained from Pfizer (São Paulo, Brazil) and the internal standard, tioconazole, from Galena 
(China). Ethyl acetate (HPLC grade) was from Burdick \& Jackson, USA) and reagent grade water (Milli- ${ }^{\circledR}$, Millipor Corp.) was used.

\section{Chromatography}

Analyses were performed on a GC-MS Shimadzu QP5050A instrument employing the following conditions: Column: CBP-5 (Shimadzu) fused silica capillary column $(30 \mathrm{~m}$ long $\times 0.25 \mathrm{~mm}$ i.d. $\times 0.25 \mathrm{~mm}$ film thickness composed of 5\% phenylmethylpolysiloxane) connected to an ion trap detector operating in EI mode at $70 \mathrm{eV}$; carrier gas: $\mathrm{He}(1 \mathrm{~mL} / \mathrm{min})$; injector and ion-source temperatures were $300{ }^{\circ} \mathrm{C}$ and a split ratio of 1:5. Injection volume was $1 \mathrm{~mL}$ (ethyl acetate) and the oven temperature was programmed from $160{ }^{\circ} \mathrm{C}$ (isothermal for $1 \mathrm{~min}$ ), with an increase of $35^{\circ} \mathrm{C} / \mathrm{min}$, to $270{ }^{\circ} \mathrm{C}$, then isothermal for 10 min. Tioconazol, $10.0 \mu \mathrm{g}$, was used as internal standard. Concentrations of fluconazole in the maternal serum and amniotic fluid samples were derived by interpolation of the ratio between peak areas in the calibration curve.

\section{Sample collection}

Eight pregnant Wistar rats were treated by gavage with a $20 \mathrm{mg} / \mathrm{ml}$ suspension of fluconazole at a dose of $100 \mathrm{mg} / \mathrm{kg}$, during organogenesis (from the $6^{\text {th }}$ to the $15^{\text {th }}$ gestation day). On the $15^{\text {th }}$ day, two hours after the last dose of fluconazole, the rats were anaesthetized by ethyl ether inhalation and the peritoneal and thoracic cavities were opened. Maternal blood was collected from the heart and immediately centrifuged at $2500 \mathrm{~g}$ for $5 \mathrm{~min}$. Then serum was removed and frozen until assay. Uteri were dissected longitudinally and the amniotic fluids from each maternal-fetal unit were collected and frozen until analysis. The approval for the use of animals and for the procedures required for the experiments was obtained by the Ethical Committee for Animal Use in Experimental Studies of the Universidade Federal de Goiás.

\section{Sample preparation}

To both $0.5 \mathrm{~mL}$ of maternal serum and amniotic fluid, $1.0 \mathrm{~mL}$ of water was added. The samples were then extracted with $6 \mathrm{~mL}$ of ethyl acetate by vortex-mixing for one minute. After $10 \mathrm{~min}$ centrifugation at $1400 \mathrm{~g}, 25^{\circ} \mathrm{C}$, $5.0 \mathrm{~mL}$ of the organic layer were transferred to a clean tube and evaporated to dryness under $\mathrm{N}_{2}$ (Kim et al., 1994). The internal standard, $20.0 \mu \mathrm{L}$ tiocanazole ( $5000.0 \mu \mathrm{g} / \mathrm{mL}$ in ethyl acetate), was added to the residue and the volume was made up to $200.0 \mu \mathrm{L}$ with ethyl acetate. An aliquot of $1.0 \mu \mathrm{L}$ of the mixture was injected in the column.

\section{RESULTS}

\section{Specificity}

The specificity of the assay was examined by comparing the chromatogram of the drug-free serum sample with that of standard solution of fluconazole and tioconazole. Retention times (RT) of fluconazole and tioconazole were approximately 5.37 and $11.7 \mathrm{~min}$, respectively. Typical chromatograms are shown in Figure 1. The total run time for each sample injection was about $15 \mathrm{~min}$. There were no interfering peaks in the blank serum at the retention times of fluconazole and the internal standard.

\section{Linearity}

Standard solutions were prepared by dissolving fluconazole in ethyl acetate, within a concentration range of $10.0-300.0 \mu \mathrm{g} / \mathrm{mL}(n=6)$. At each concentration level internal standard, tioconazole $(10.0 \mu \mathrm{g})$, was added and the solutions were analysed in triplicate. Calibration curve was derived by plotting the peak-height ratios of fluconazole

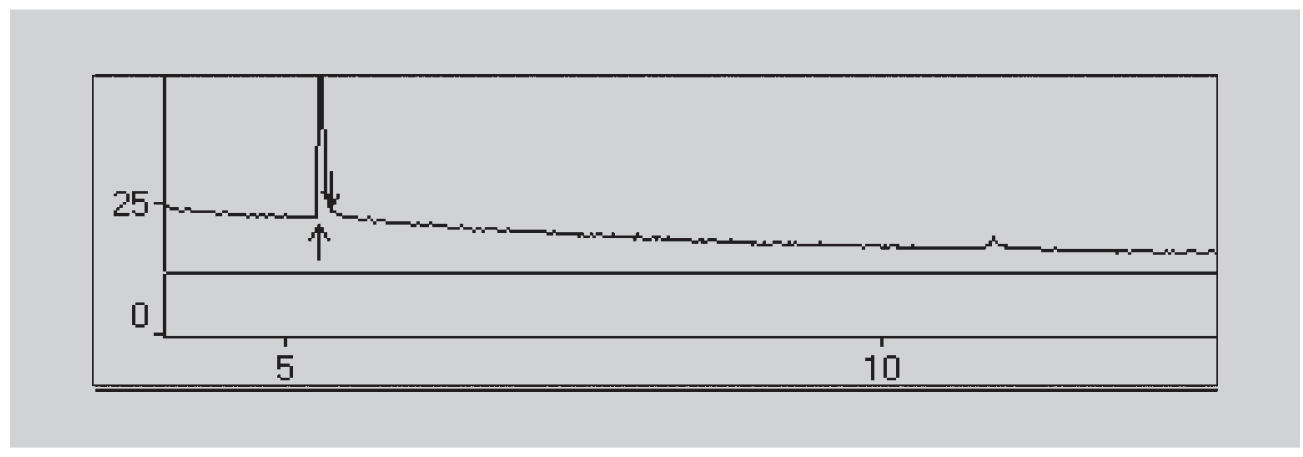

FIGURE 1 - GC chromatogram of fluconazole (concentration $50 \mathrm{mg} / \mathrm{ml}$, RT 5,37 $\mathrm{min}$ ) and tioconazole (concentration $10 \mathrm{mg} / \mathrm{mL}$, RT $11,7 \mathrm{~min})$. 
and internal standard in standard solutions against the known concentrations of fluconazole, using linear regression analysis. The equation obtained was $\mathrm{y}=$ $0.19754 \mathrm{x}-1.39985$, correlation coefficient $r=0.9997$.

\section{Limit of quantification}

Limit of quantification defined as the lowest concentration with an R.S.D. $=20 \%$ was $0.1 \mu \mathrm{g} / \mathrm{mL}$.

\section{Recovery}

For recovery studies, serum samples were spiked with fluconazole at three different concentrations $(50,100$ and $200 \mu \mathrm{g} / \mathrm{mL}$ ) and three samples from each concentration, were extracted using the assay procedure. After dryness, $20.0 \mu \mathrm{L}$ of the internal standard, $(5000.0 \mu \mathrm{g} / \mathrm{mL}$ in ethyl acetate), was added to the residue and the volume was made up to $200.0 \mu \mathrm{L}$ with ethyl acetate, $1.0 \mu \mathrm{L}$ aliquot of the mixture was analysed. The recovery was calculated from the peak areas of the spiked samples and the peak areas of standard solutions in the same concentration ranges. The efficiency of the extraction was greater than $90 \%$ in the three concentrations (Table I).

\section{Precision and accuracy}

Blank serum samples were spiked with fluconazole at three concentration levels (50,100 and $200 \mu \mathrm{g} / \mathrm{mL}$ ), at each concentration internal standard was added. Six replicates of each solution were analysed and the coefficients of variation (C.V.) were calculated using the mean of the concentrations found and S.D. For this study the variances were acceptable, with C.V. values below 5\% (Table I). Accuracy (bias) for fluconazole was expressed as the percentage deviation of observed concentration from theoretical concentration; the greatest bias was equal to $3.8 \%$ (Table I).

\section{Maternal serum and amniotic fluid samples}

Typical GC chromatograms of serum and amniotic fluid samples of rats treated with fluconazole are shown in Figure 2.

TABLE I - Results obtained from method validation: precision (C.V.), accuracy (bias) and the recovery of fluconazole from the spiked serum samples

\begin{tabular}{ccccc}
\hline $\begin{array}{c}\text { Spiked serum samples } \\
(\boldsymbol{\mu g} / \mathbf{m L})\end{array}$ & $\begin{array}{c}\text { Conc. found } \\
(\boldsymbol{\mu g} / \mathbf{m L}) \\
\text { mean } \pm \text { S.D. }\end{array}$ & $\begin{array}{c}\text { C.V. } \\
(\mathbf{\%})\end{array}$ & $\begin{array}{c}\text { Bias } \\
(\%)\end{array}$ & $\begin{array}{c}\text { Mean recovery } \\
(\boldsymbol{\%})\end{array}$ \\
\hline 50 & $49.4 \pm 1.8$ & 3.6 & -1.2 & $92.5 \pm 6.7$ \\
100 & $96.2 \pm 4.6$ & 4.8 & -3.8 & $93.2 \pm 4.9$ \\
200 & $195.3 \pm 7.5$ & 3.8 & -2.4 & $91.8 \pm 7.3$ \\
\hline
\end{tabular}

* Calculated from calibration curve for spiked serum samples $(n=6)$.
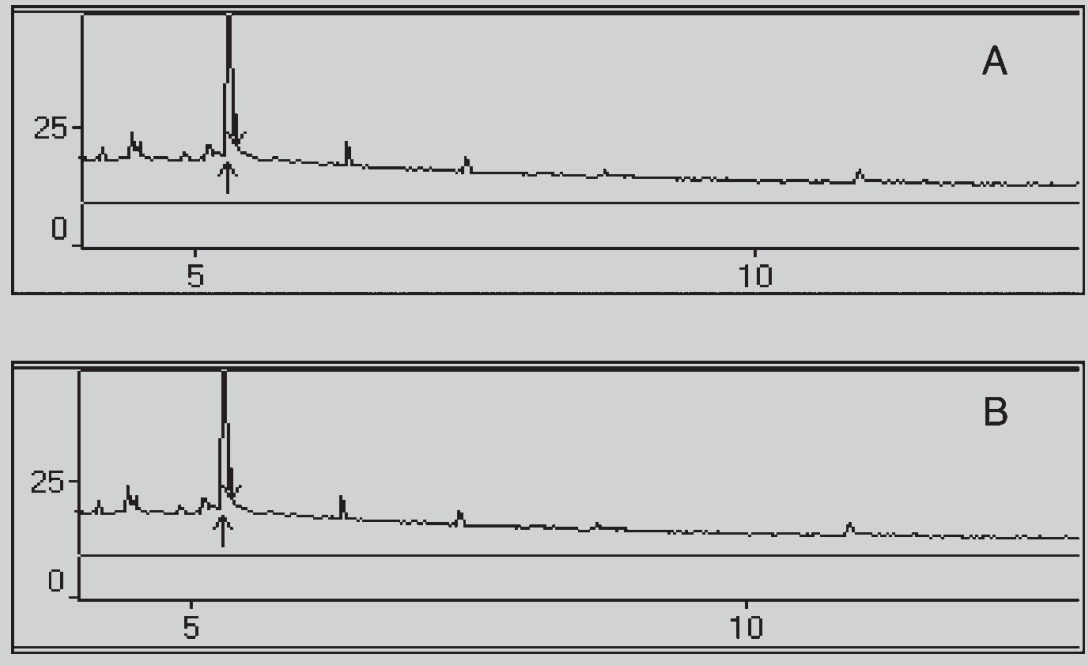

FIGURE 2 - GC Chromatograms of fluconazole (5.37 min) and internal standard (tioconazole, $11.7 \mathrm{~min}$ ). (A) serum sample and (B) amniotic liquid sample, obtained from rats treated with fluconazole. 
Table II presents the concentrations of fluconazole determined in maternal serum and amniotic fluid after two hours of the last oral administration of the drug. The treatment lasted ten days (from $6^{\text {th }}$ to $15^{\text {th }}$ day of gestation) and the mean concentrations of fluconazole in maternal serum and in amniotic fluid were $206.01 \pm 105.25 \mu \mathrm{g} / \mathrm{mL}$ and $125.34 \pm 65.24 \mu \mathrm{g} / \mathrm{mL}$, respectively.

TABLE II - Fluconazole concentration detected in serum and amniotic liquid samples from rats treated at a dose of $100 \mathrm{mg} / \mathrm{kg}$, during organogenesis

\begin{tabular}{ccc}
\hline $\begin{array}{c}\text { Treated } \\
\text { Rats } \\
(\mathbf{n}=\mathbf{8})\end{array}$ & $\begin{array}{c}\text { Fluconazole } \\
\text { concentration in } \\
\text { serum }(\mathbf{m g} / \mathbf{m L})\end{array}$ & $\begin{array}{c}\text { Fluconazole } \\
\text { concentration in } \\
\text { amniotic liquid } \\
(\mathbf{m g} / \mathbf{m L})\end{array}$ \\
\hline Rat 1 & 273.02 & 170.34 \\
Rat 2 & 321.41 & 100.57 \\
Rat 3 & 126.70 & 91.55 \\
Rat 4 & 170.94 & 157.44 \\
Rat 5 & 48.55 & 25.04 \\
Rat 6 & 107.42 & 60.70 \\
Rat 7 & 296.18 & 194.56 \\
Rat 8 & 303.86 & 202.52 \\
mean \pm S.D. & $206.01 \pm 105.25$ & $125.34 \pm 65.24$ \\
\hline
\end{tabular}

\section{DISCUSSION}

Quantification of fluconazole in serum and amniotic fluid of Wistar rats was possible using the present method. The preparation of sample is easy followed by GC/MS analysis with a simple capillary column. Previous GC assays for fluconazole quantitative determination described a pretreatment of the packed column with benzoyl chloride (Wood, Tarbit, 1986), or indicated the use of a semi-capillary column (Beijnen et al., 1991) with low efficiency. In both methods an electron capture detector was used, which is less selective than the ion trap deterctor. In the present method, column deactivation and derivatization of fluconazole were unnecessary; even so the limit of detection was $0.1 \mu \mathrm{g} / \mathrm{ml}$. This fact shows the sensitivity of the proposed method. HPLC analysis of fluconazole using UV detector (Koks et al., 1995; $\mathrm{Ng}$ et al., 1996; Majcherczyk et al., 2002) showed to be less sensitive than GC/MS method. Recently a very sensitive HPLC/MS/MS method (Eerkes et al., 2003) has been published, however, unfortunately these instruments have not become commonly available in all laboratories yet.

\section{CONCLUSION}

A simple, specific and rapid GC/MS method for the measurement of fluconazole concentrations, in serum and amniotic fluid, is described. It offers a suitable alternative to the existing GC and HPLC techniques and it can be used to quantify fluconazole and tioconazole in biological fluids for teratogenic and pharmacokinetic studies.

\section{ACKNOWLEDGEMENTS}

The authors are indebted to CNPq/PCOP (\# 520769/99-6), PADCT III (\# 620166/97-5) and FUNAPE/UFG for financial support.

\section{RESUMO}

\section{Determinação de fluconazol em soro e líquido amniótico de ratas por cromatografia a gas/ espectrometria de massas (CG/EM)}

Soro e líquido amniótico de ratas tratadas com fluconazol (dose oral de $100 \mathrm{mg} / \mathrm{kg}$ ) durante a prenhez foram quantificados para este fármaco usando cromatografia gasosa acoplada à espectroscopia de massas (CG/EM). O fluconazol foi extraído das amostras com acetato de etila e analisado empregando-se um cromatógrafo CG/EM Shimadzu QP5050A com coluna capilar de sílica fundida CBP-5. O tioconazol foi utilizado como padrão interno. A curva padrão foi linear no intervalo das concentrações de 10,0 a 300,0 $\mu \mathrm{g} / \mathrm{mL}$. O limite de quantificação foi de $0,1 \mu \mathrm{g} / \mathrm{mL}$ e não foi observada interferência no branco de soro e líquido amniótico. As concentrações médias do fármaco no soro e líquido amniótico foram 206,01 $\pm 105,25 \mu \mathrm{g} / \mathrm{mL}$ e 125,34 \pm $65,24 \mu \mathrm{g} / \mathrm{mL}$, respectivamente. Este procedimento mostrou-se sensivel e eficiente para ser usado em estudos de teratogenicidade do fluconazol e outros azóis.

UNITERMOS: Fluconazol. CG/EM. Soro. Liquido amniótico.

\section{REFERENCES}

BEIJNEN, J.H.; MEENHORST, P.L.; GIJN, R.; HAZELAGER, W.A.; KOKS, C.H.W., UNDERBERG, W.J.M. Gas chromatographic analysis, with electron capture detection, of the antifungal drug fluconazole in microvolumes of human plasma. J. Pharm. Biomed. Anal., v.9, p.1173-1175, 1991. 
DEBRUYNE, D.; RYCKELYNCK, J.P. Clinical pharmacokinetics of fluconazole. Clin. Pharmacok., v.24, p.10-27, 1993.

EERKES, A.; SHOU, W.Z.; NAIDONG, W. Liquid/liquid extraction using 96-well plate format in conjunction with hydrophilic interaction liquid chromatography-tandem mass spectrometry method for the analysis of fluconazole in human plasma. J. Pharm. Biomed. Anal., v. 31, p.917928, 2003.

KIM, H.; LAPIGUERA, A.; LIN, C. Gas chromatographic and high-performance liquid chromatographic methods for the determination of genazole in biological fluids. $J$. Chromatogr. B, v. 655, p.21-26, $1994 .$.

KING, C.T.; ROGERS, P.D.; CHAPMAN, S.W. Antifungal therapy during pregnancy. Clin. Infect. Dis., v.27, p.11511160, 1998 .

KOKS, C.H.W.; ROSING, H.;MEENHORST, P.L.; BULT, A.; BEIJNEN, J.H. High-performance liquid chromatographic determination of the antifungal drug fluconazole in plasma and saliva of human immunodefiency virus-infected patients. J. Chromatogr. $B$, v. 663, p.345-351, 1995.

MAJCHERCZYK, P.A.; MOREILLON, P.; DECOSTERD, L.A.;SANGLARD, D.; BILLE, J.; GLAUSER, M.P.; MARCHETTI, O. Single-step extraction of fluconazole from plasma by ultra-filtration for the measurement of its free concentration by high performance liquid chromatography. J. Pharm. Biomed. Anal., v. 28, p.645-651, 2002.

MASTROIACOVO, P.; MAZZONE, T.;BOTTO, L.D.; SERAFINI, M.A.; FINARDI, A.; CARAMELLI, L.; FUSCO, D. Prospective assessment of pregnancy outcomes after first-trimester exposure to fluconazole. Am. J. Obstetr. Gynecol., v.175, p.1645-1650, 1996.
NG, T.K.C.; CHAN, R.C.Y.;ADEYEMI-DORO, F.A.B.; CHEUNG, S.W.; CHENG, A.F.B. Rapid high performance liquid chromatographic assay for antifungal agents in human sera. J. Antimicr. Chemother., v. 37, p.465-472, 1996.

POLIFKA, J.E.; FRIEDMAN, J.M. Clinical teratology: identifying teratogenic risks in humans. Clin. Genet., v.56, p.409-420, 1999.

PURSLEY, T.J.; BLOMQUIST, I.K.; ABRAHAM, J.; ANDERSEN, H.F., BARTLEY, J.A. Fluconazoleinduced congenital anomalies in three infants. Clin. Infect. Dis., v.22, p.336-340, 1996.

RICHARDSON, K.; BRAMMER, K.W.; MARRIOTT, M.S.; TROKE, P.F. Activity of UK-49,858, a bis-triazole derivative, against experimental infections with Candida albicans and Trichophyton mentagrophytes. Antimicr. Agents Chemother., v.27, p.832-835, 1985.

RIPA, S.; FERRANTE, L.; PRENNA, M. Pharmacokinetics of fluconazole in normal volunteers. Chemotherapy, v.39, p.6-12, 1993.

WOOD, P.R., TARBIT, M.H. Gas chromatographic method for the determination of fluconazole, a novel antifungal agent, in human plasma and urine. J. Chromatogr., v.383, p.179-186, 1986.

Recebido para publicação em 03 de fevereiro de 2004. Aceito para publicação em 04 de abril de 2005. 